\section{THE SIPRI TOP 100 ARMS-PRODUCING COMPANIES, 2008}

SUSAN T. JACKSON AND THE SIPRI ARMS INDUSTRY NETWORK*

\section{HIGHLIGHTS}

The total arms sales of the world's 100 largest arms-producing companiesthe SIPRI Top 100-increased by $\$ 39$ billion in 2008 to reach $\$ 385$ billion. While companies headquartered in the United States again dominate the Top 100, for the first time a non-US company-BAE Systems of the United Kingdom-heads the list with the highest arms sales. ${ }^{1}$ The wars in Afghanistan and Iraq continued to heavily influence sales of military equipment such as armoured vehicles, unmanned aerial vehicles (UAVs) and helicopters in 2008. At the same time, sales by military services companies continued to grow, as did the arms sales of Russian companies to both domestic and foreign customers.

The Top 100 for 2008 contains 45 North American companies (all but one of them US-headquartered), accounting for 60 per cent of the arms sales of the Top 100; 34 West European companies, accounting for 32 per cent of arms sales; 7 Russian companies, accounting for 3 per cent of arms sales; and companies from Japan, Israel, India, South Korea and Singapore.

A Russian company-Almaz-Antei-is among the world's 20 largest armsproducing companies for the first time. The US company Navistar-manufacturer of mine-resistant ambush-protected (MRAP) vehicles-entered the SIPRI Top 100 at 20th place, having increased arms sales by 960 per cent in just one year. Boeing is the only one of the top 20 arms producers to have decreased arms sales in 2008-down from \$30 billion in 2007 to $\$ 29$ billion in 2008.

The SIPRI Top 100 for 2008 appears in table 1. For full details and analysis, see SIPRI Yearbook 2010. ${ }^{2}$

\footnotetext{
${ }^{1}$ The internationalization of the arms-producing industry means that companies based in one country often belong to a company or group with headquarters in another country. In this fact sheet, a company's country designation refers to the location of a company's headquarters.

2 Jackson, S. T., 'Arms production', SIPRI Yearbook 2010: Armaments, Disarmament and International Security (Oxford University Press: Oxford, forthcoming 2010).

* Participants in the network for 2008 were Gülay Günlük-Şenesen (Istanbul University), Jean-Paul Hébert (Centre Interdisciplinaire de Recherches sur la Paix et d'Etudes Stratégiques, Paris), Shinichi Kohno (Mitsubishi Research Institute, Tokyo), Valerie Miranda (Istituto Affari Internazionali, Rome), Pere Ortega (Centre d'Estudis per la Pau J. M. Delàs, Barcelona) and Paek Jae Ok (Korea Institute for Defense Analyses, Seoul).
}

\section{KEY FACTS}

- The total arms sales of the SIPRI Top 100 arms-producing companies in 2008 (outside China) increased by $\$ 39$ billion to reach $\$ 385$ billion.

- For the first time, a non-US company heads the list: BAE Systems of the UK.

- US companies still dominate the list: 44 of the Top 100 companies are USheadquartered; they account for 60 per cent of the arms sales of the Top 100.

- West European companies follow, with 34 companies that make 32 per cent of the Top 100's arms sales.

- A Russian company-AlmazAntei-is one of the 20 largest arms-producing companies for the first time.

- No Australian-owned company appears in the SIPRI Top 100 for 2008 following BAE Systems' acquisition of Tenix Defence Systems in early 2008. - Hewlett-Packard entered the Top 100 at rank 30 following its acquisition of EDS.

- Only 6 companies in the SIPRI Top 100 had decreased arms sales in 2008.

- 13 companies increased their arms sales by more than $\$ 1$ billion in 2008 and 23 increased their arms sales by more than 30 per cent. - Factors behind these increases include: military equipment procurement for the wars in Afghanistan and Iraq; increasing sales of military services; and, for Russian companies, government support, force modernization and increased arms sales abroad. 


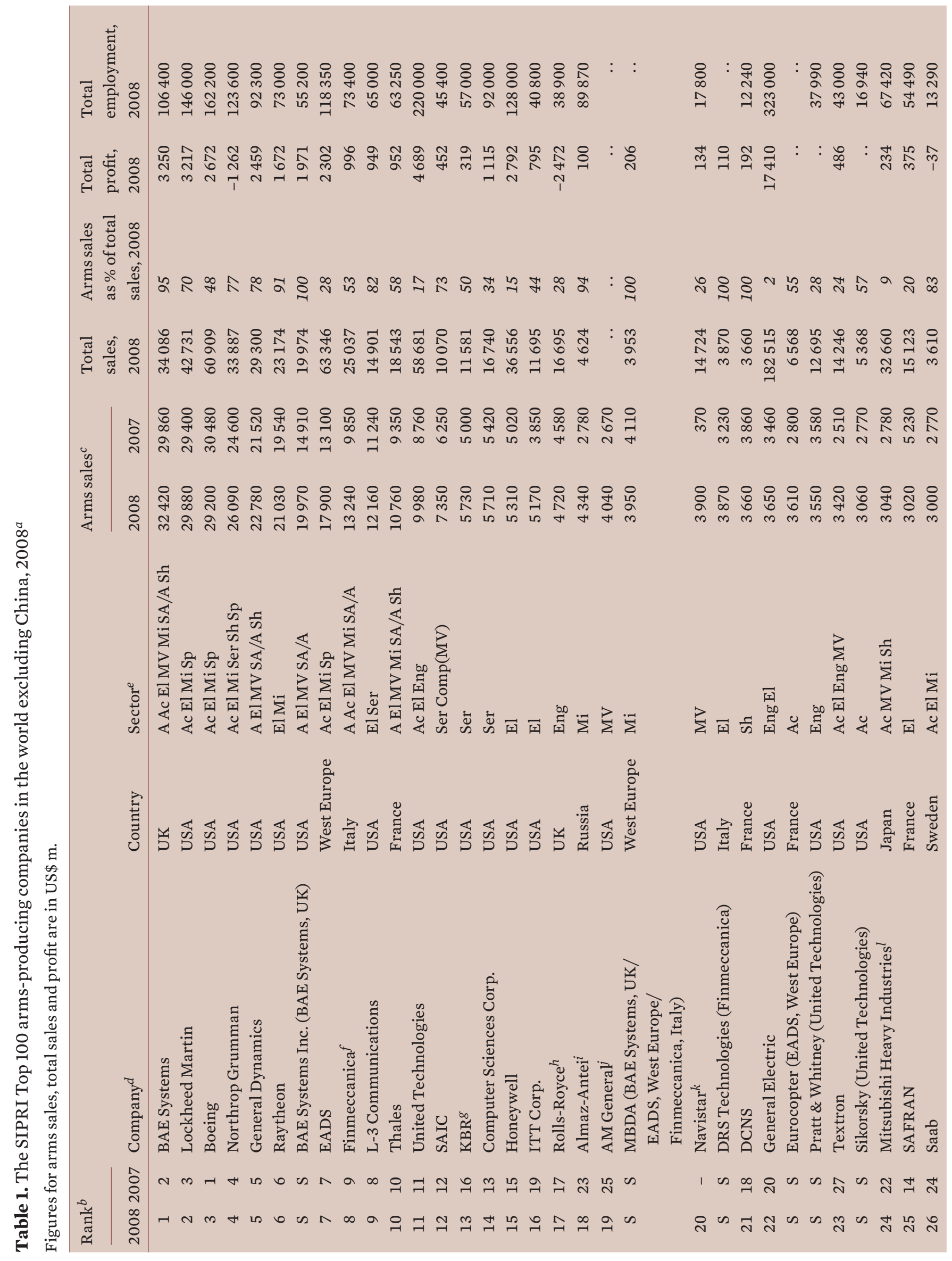




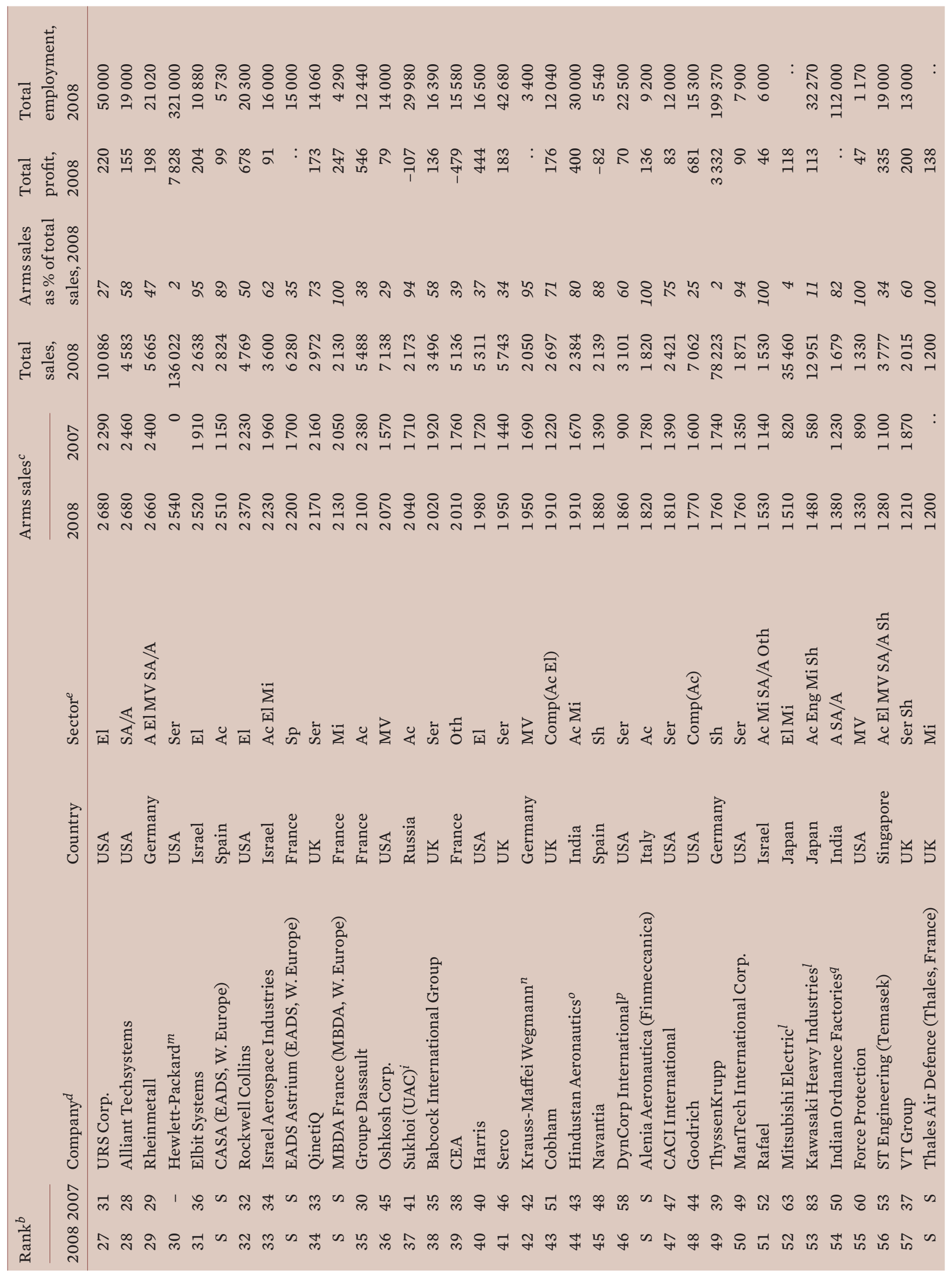




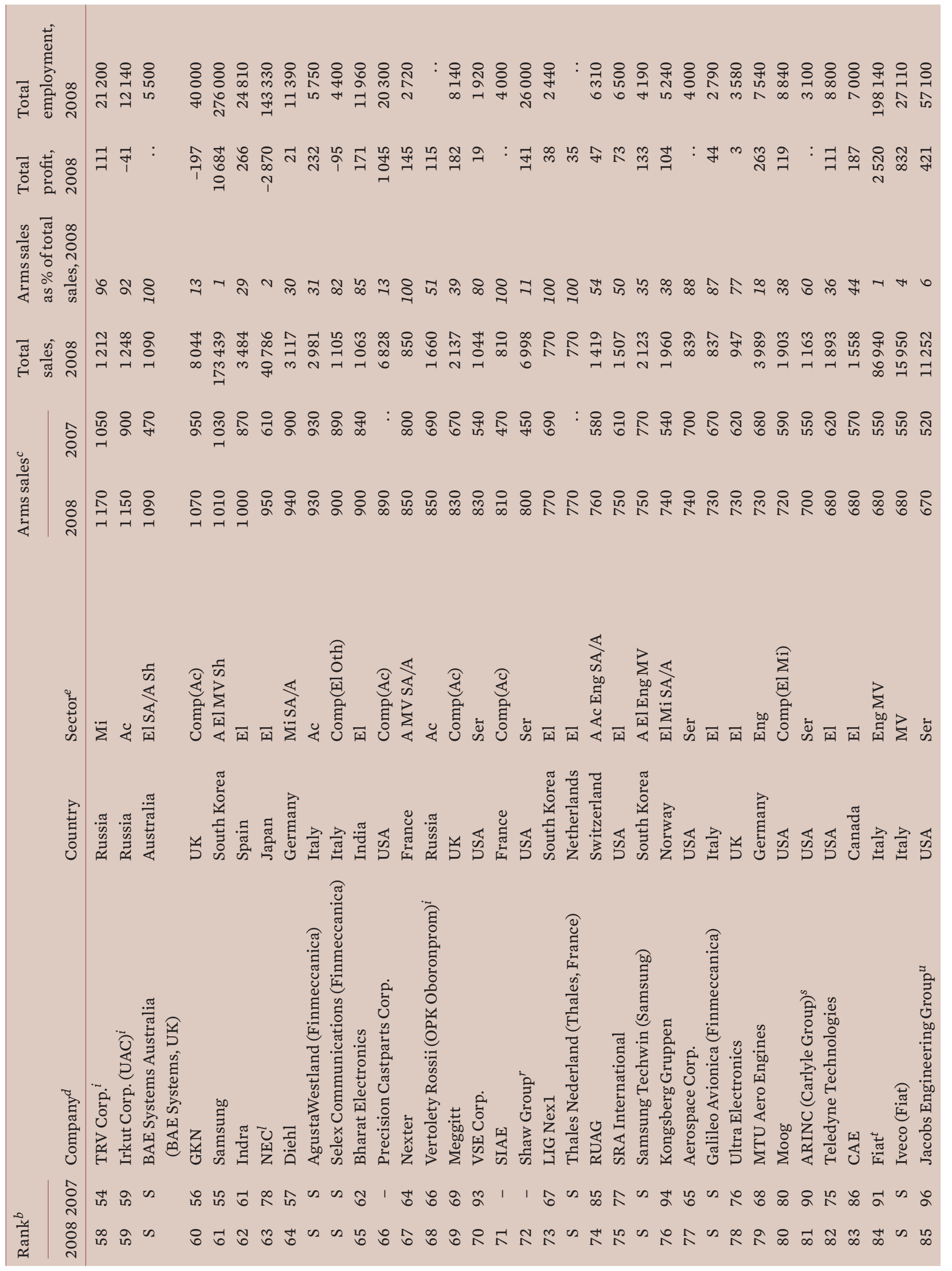




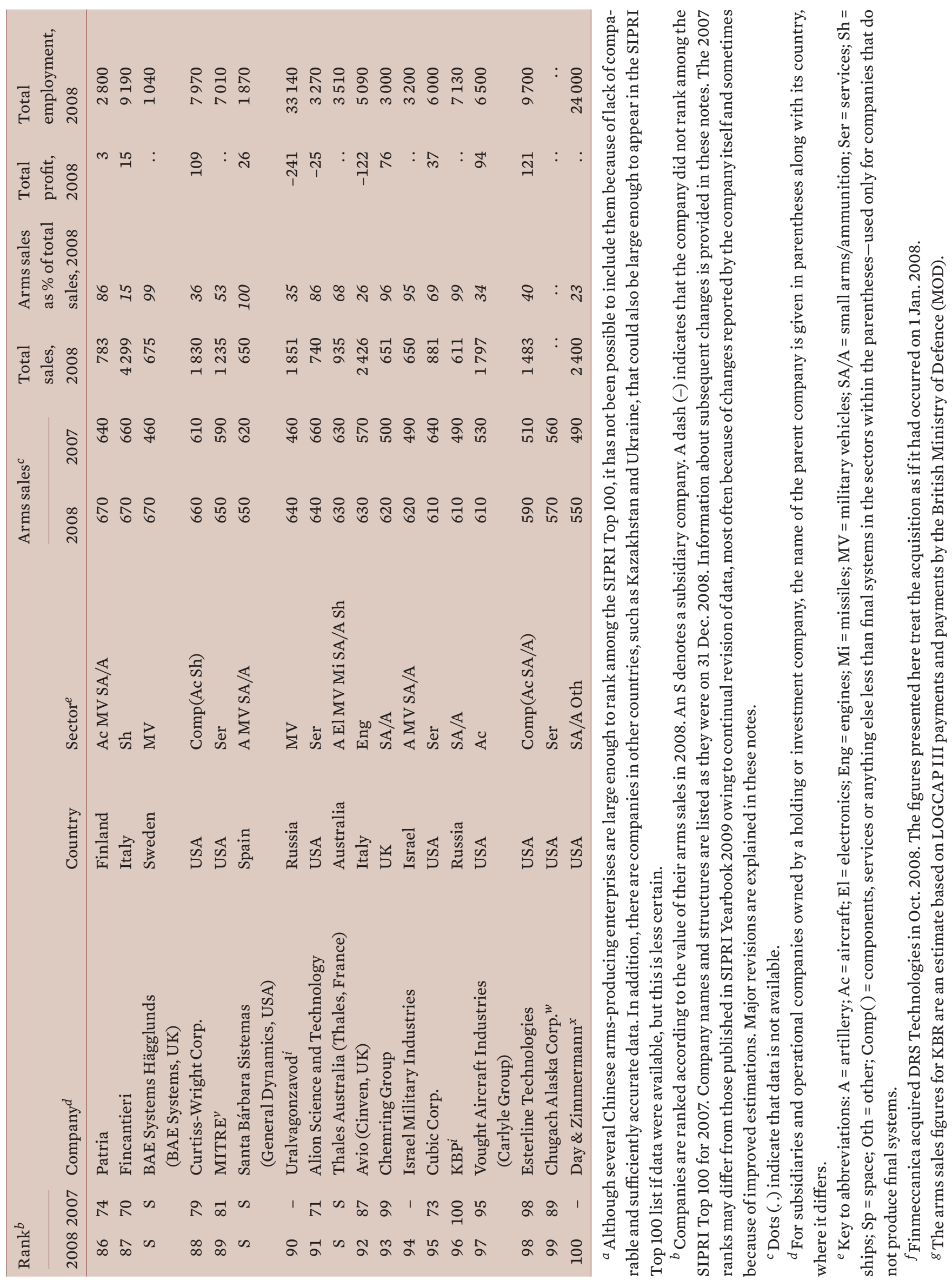




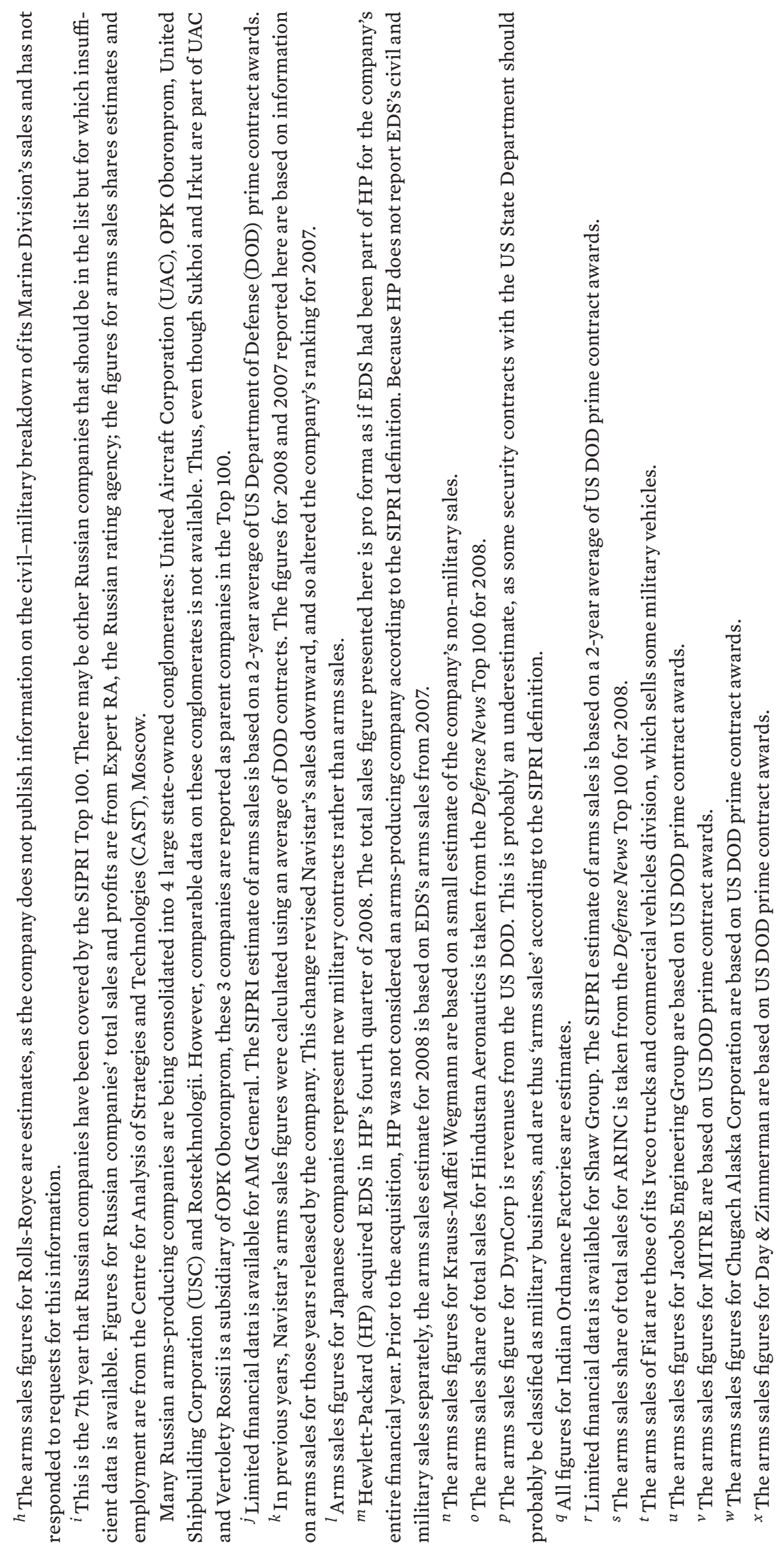




\section{SOURCES AND METHODS}

\section{Selection criteria and sources of data}

Table 1 lists the world's 100 largest arms-producing companies (excluding Chinese companies), ranked by their arms sales in 2008-the SIPRI Top 100 for 2008. The table contains information on each company's arms sales in 2007 and 2008 and its total sales, profit and employment in 2008. It includes public and private companies but excludes manufacturing or maintenance units of the armed services. Only companies with operational activities in the field of military goods and services are listed, not holding or investment companies. Chinese companies are excluded because of the lack of readily available data. Companies from other countries might also have been included at the lower end of the list had sufficient data been available.

Publicly available information on arms sales and other financial and employment data on the arms industry worldwide are limited. The sources of data for table 1 include company annual reports and websites, a SIPRI questionnaire, and news published in the business sections of newspapers, in military journals and by Internet news services specializing in military matters. Press releases, marketing reports, government publications of contract awards and country surveys are also consulted. Where no data is available from these sources, SIPRI has made estimates (see below). The scope of the data and the geographical coverage are largely determined by the availability of information. All the data is continuously revised and updated and may change between different editions of the SIPRI Yearbook.

\section{Definitions}

Arms sales are defined by SIPRI as sales of military goods and services to military customers, including both sales for domestic procurement and sales for export. Military goods and services are those which are designed specifically for military purposes and the technologies related to such goods and services. Military goods are military-specific equipment and do not include general purpose goods, such as oil, electricity, office computers, uniforms and boots. Military services are also military-specific. They include technical services such as information technology, maintenance, repair and overhaul, and operational support; services related to the operation of the armed forces, such as intelligence, training, logistics and facilities management; and armed security in conflict zones. They do not include the peacetime provision of purely civilian services, such as health care, cleaning, catering, and transportation, but supply services to operationally deployed forces are included.

This definition of arms sales serves as a guideline; in practice it is difficult to apply. Nor is there any good alternative, since no generally agreed standard definition exists. The data on arms sales in table 1 often reflects only what each company considers to be the defence share of its total sales. The comparability of the company arms sales figures given in table 1 is therefore limited.

Data on total sales, profit and employment is for entire companies, not for arms-producing divisions alone. All data is for consolidated sales, including those of national and foreign subsidiaries. The data on profit represents profit after taxes. Employment data is year-end figures, except for those 
SIPRI is an independent international institute dedicated to research into conflict, armaments, arms control and disarmament. Established in 1966, SIPRI provides data, analysis and recommendations, based on open sources, to policymakers, researchers, media and the interested public.

\section{GOVERNING BOARD}

Ambassador Rolf Ekéus,

Chairman (Sweden)

Dr Dewi Fortuna Anwar

(Indonesia)

Dr Alexei G. Arbatov (Russia)

Ambassador Lakhdar Brahimi (Algeria)

Jayantha Dhanapala

(Sri Lanka)

Dr Nabil Elaraby (Egypt)

Ambassador Wolfgang

Ischinger (Germany)

Professor Mary Kaldor

(United Kingdom)

The Director

\section{DIRECTOR}

Dr Bates Gill (United States)

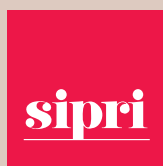

STOCKHOLM INTERNATIONAL PEACE RESEARCH INSTITUTE

Signalistgatan 9

SE-169 70 Solna, Sweden

Telephone: +4686559700

Fax: +4686559733

Email: sipri@sipri.org

Internet: www.sipri.org companies that publish only a yearly average. All data is presented on the financial year basis reported by the company in its annual report.

\section{Calculations}

Arms sales are sometimes estimated by SIPRI. In some cases SIPRI uses the figure for the total sales of a 'defence' division, although the division may also have some, unspecified, civil sales. When the company does not report a sales figure for a defence division or similar entity, estimates can sometimes be made based on data on contract awards, information on the company's current arms production programmes and figures provided by company officials in media or other reports.

The data for arms sales is used as an approximation of the annual value of arms production. For most companies this is realistic. The main exception is shipbuilding companies. For these companies there is a significant discrepancy between the value of annual production and annual sales because of the long lead (production) time of ships and the low production run (number). Some shipbuilding companies provide estimates of the value of their annual production. This data is then used by SIPRI for those companies.

All data is collected in local currency and at current prices. For conversion from local currencies to US dollars, SIPRI uses the International Monetary Fund (IMF) annual average of market exchange rates (as provided in International Financial Statistics). The data in table 1 is provided in current dollars. Changes between years in this data is difficult to interpret because the change in dollar values is made up of several components: the change in arms sales, the rate of inflation and, for sales conducted in local currency, fluctuations in the exchange rate. Sales on the international arms market are often conducted in dollars. Fluctuations in exchange rates then do not have an impact on the dollar values but affect instead the value in local currency. If the value of the dollar declines, then the company's revenue in local currency falls and, if its production inputs are paid for in local currency-which most often is the case-this has a negative impact on the company's profit margins. Calculations in constant dollar terms are difficult to interpret for the same reasons. Without knowing the relative shares of arms sales derived from domestic procurement and from arms exports, it is impossible to interpret the exact meaning and implications of the arms sales data. This data should therefore be used with caution. This is particularly true for countries with strongly fluctuating exchange rates. 